\title{
In vitro evaluation of the effectiveness of the chemomechanical preparation against Enterococcus faecalis after single- or multiple-visit root canal treatment
}

\author{
Avaliação in vitro da efetividade do preparo \\ químico-mecânico frente ao Enterococcus \\ faecalis após tratamento endodôntico realizado \\ em uma ou em múltiplas sessões
}

Eduardo Diogo Gurgel-Filho(a) Nilton Vivacqua-Gomes ${ }^{(b)}$

Brenda Paula Figueiredo de Almeida Gomes $^{(c)}$

Caio Cezar Randi Ferraz (c)

Alexandre Augusto Zaia(c)

Francisco José de Souza-Filho(c)

(a) Adjunct Professor, Department of Endodontics, University of Fortaleza.

(b) Professor, Brazilian Dental Association, Fortaleza.

(c)Adjunct Professors, School of Dentistry of Piracicaba, State University of Campinas.

\author{
Corresponding author: \\ Eduardo Diogo Gurgel-Filho \\ Av. Dom Luis, 1233/31 1, Aldeota \\ Fortaleza - CE - Brazil \\ CEP: 60160-230 \\ E-mail:gurgeleduardo@unifor.br
}

Received for publication on Sep 08, 2006 Sent for alterations on Feb 02, 2007

Accepted for publication on Apr 27, 2007

\begin{abstract}
The purpose was to assess the elimination of Enterococcus faecalis in vitro in human mandibular premolars after chemomechanical preparation with or without the use of a calcium hydroxide dressing. After 60 days of contamination with E. faecalis, the root canals were prepared using the Crown-Down technique combined with $2 \%$ chlorhexidine gel irrigation. Then, the specimens were divided into two experimental groups, treated in a single visit or in multiple visits, and two control groups. The multiple-visit group received a dressing with calcium hydroxide for 14 days $\left(\mathrm{Calen}^{\mathrm{TM}}\right)$ and the single-visit group did not receive any medication. In the two control groups, the canals were filled with BHI after chemomechanical preparation with $2 \%$ chlorhexidine gel or distilled water. Microbial samples were taken from the root canals for colony forming unit count for each phase of the treatment using sterile paper points inside the root canal lumen. Data were ranked and analyzed by the KruskalWallis statistical test. The residual microbial colonies were then assessed. The results showed that chemomechanical preparation using $2 \%$ chlorhexidine gel with no intra-canal dressing reduced by $100 \%$ the E. faecalis contamination of the root canal lumen. The calcium-hydroxide group that received the 14-day intra-canal dressing allowed a small number of bacteria to grow between visits, but without statistical differences between groups.

Descriptors: Dental pulp cavity; Chlorhexidine; Calcium hydroxide; Enterococcus faecalis.
\end{abstract}

Resumo: Objetivou-se avaliar in vitro a eliminação do Enterococcus faecalis em pré-molares inferiores humanos após o preparo químico-mecânico seguido ou não de curativo de hidróxido de cálcio. Após 60 dias de contaminação com E. faecalis os canais radiculares foram preparados utilizando-se a técnica coroa-ápice associada à irrigação com clorexidina em gel a $2 \%$. Posteriormente os espécimes foram divididos em dois grupos experimentais, tratados em uma ou duas sessões, e dois grupos controles. O grupo tratado em duas sessões recebeu medicação intracanal de hidróxido de cálcio por 14 dias $\left(\right.$ Calen $\left.^{\mathrm{TM}}\right)$ e o grupo de sessão única não recebeu medicação. Nos dois grupos controles, após o preparo químico-mecânico com clorexidina em gel a $2 \%$ ou água destilada, os canais foram preenchidos com BHI. Amostras microbiológicas foram coletadas dos canais radiculares e contadas por meio de unidades formadoras de colônia em cada fase do tratamento utilizando-se ponta de papel dentro da luz do canal. Os dados foram analisados estatisticamente pelo teste de Kruskal-Wallis. As colônias bacterianas residuais foram então mensuradas. A utilização da clorexidina em gel a $2 \%$ sem emprego da medicação intracanal reduziu em $100 \%$ a contaminação por E. faecalis. O grupo que recebeu a medicação intracanal de hidróxido de cálcio por 14 dias permitiu o crescimento de pequeno número de bactérias entre as sessões, mas sem diferença estatística entre os grupos.

Descritores: Cavidade da polpa dentária; Clorexidina; Hidróxido de cálcio; Enterococcus faecalis. 


\section{Introduction}

Root canal treatments in a single visit or in multiple visits should be viewed as part of a total endodontic treatment spectrum, with the choice of one over the other being determined by the circumstances peculiar to each particular case and then the technique being chosen that best fits those circumstances. $^{2}$

Peters, Wesselink ${ }^{15}$ (2002) showed that positive cultures immediately before root canal filling did not influence the outcome of the treatment in both single- and multiple-visit treatments. Chemomechanical preparation is the most important procedure to optimize root canal disinfection since it is possible to perform root canal fillings in a single visit and obtain a similar success rate as that of treatments carried out in multiple sessions.

According to Peters et al. ${ }^{14}$ (2002), the teeth that receive calcium hydroxide intra-canal dressing, in vivo, permit microbial growth between visits. In contrast, immediate root canal filling removes all space and nutrients for continuous microbial growth. Thus, the success rate of single-visit endodontics is $92 \%$, against $93 \%$ for multiple-visit root-canal treatment, and it is an alternative to twovisit root canal treatment also in pulpless teeth. ${ }^{21}$

Gomes et al. ${ }^{7}$ (2001) studied the disinfection time of several concentrations and vehicles of chlorhexidine against $E$. faecalis. The $2.0 \%$ concentrations of liquid and gel chlorhexidine presented the shortest disinfection times, the same as with $5.25 \%$ sodium hypochlorite.

Thus, the purpose of this study was to assess root canal lumen disinfection after chemomechanical preparation using $2 \%$ chlorhexidine gel irrigation in a single-visit or in a multiple-visit root-canal treatment against Enterococcus faecalis.

\section{Material and Methods Specimen preparation}

Forty freshly extracted mandibular premolars (orthodontic reasons) with complete apex formation and foramen diameter approximated to a \#15 file were used. The crowns were removed with carburundum disks (KG Sorensen, Barueri, SP, Brazil) to the level of the amelodentinal junction, facilitating cervical access, and the teeth were instrumented to the apex using a \#25 file size (Dentsply Maillefer, Ballaigues, Vallorbe, Switzerland). The external root cementum was removed using diamond burs. ${ }^{9}$

All teeth were submitted to an ultrasonic bath for 10 minutes in $17 \%$ EDTA, followed by $10 \mathrm{~min}$ utes in a $5.25 \% \mathrm{NaOCl}$ bath, according to Perez et al. ${ }^{13}$ (1993) and a tampon phosphate bath (to eliminate EDTA and hypochlorite residues) followed by a distilled water bath (10 minutes each), in order to eliminate the smear layer produced during the initial preparation. The teeth were sterilized in bottles containing $10 \mathrm{ml}$ of Brain Heart Infusion Broth culture medium (BHI - Oxoid, Unipath Ltd., Basingstoke, Hampshire, England) for 15 minutes at $121^{\circ} \mathrm{C}$ followed by a 48 -hours incubation at $37^{\circ} \mathrm{C}$ to prove sterility. Specimens were contaminated in vitro with pure E. faecalis cultures (ATCC 29212), that were sub-cultured on plates of Brain Heart Infusion Agar (BHIA) + 5\% defibrinated sheep blood (Ebefarma, Araras, SP, Brazil) and incubated at $37^{\circ} \mathrm{C}$ for 24 hours. After bacterial growth on agar medium, isolated colonies were suspended in $10 \mathrm{ml}$ of BHI. After shaking in a vortex shaker (MA 162, Marconi, Piracicaba, SP, Brazil), bacterial suspensions were adjusted in an $800 \mathrm{~nm}$ spectrophotometer (432 Femto Marconi, Piracicaba, SP, Brazil) to produce the corresponding concentration equivalent to $1.0 \mathrm{McF}$ arland. After that, this $10 \mathrm{ml}$ bacterial suspension was added to the bottles with the teeth. This way, the bacterial concentration changed to $0.5 \mathrm{McFarland}$, used for facultative anaerobic microorganisms. ${ }^{6}$ The bottles were incubated at $37^{\circ} \mathrm{C}$ for 60 days to allow the bacteria to penetrate into the dentinal tubules, replacing the medium every 72 hours by a sterile one..$^{10}$ After a 60 -day incubation period, we could confirm bacterial penetration into the dentinal tubules by using a DSM-940A scanning electron microscope (Carl Zeiss, Thuringen, Jena, Germany) (Figure 1) and all samples were placed on agar plates to test infection rates.

\section{Procedures sequence}

The contaminated specimens were fixed in a metallic support under sterile conditions (Pachane Ltda., Piracicaba, SP, Brazil) and were instrument- 


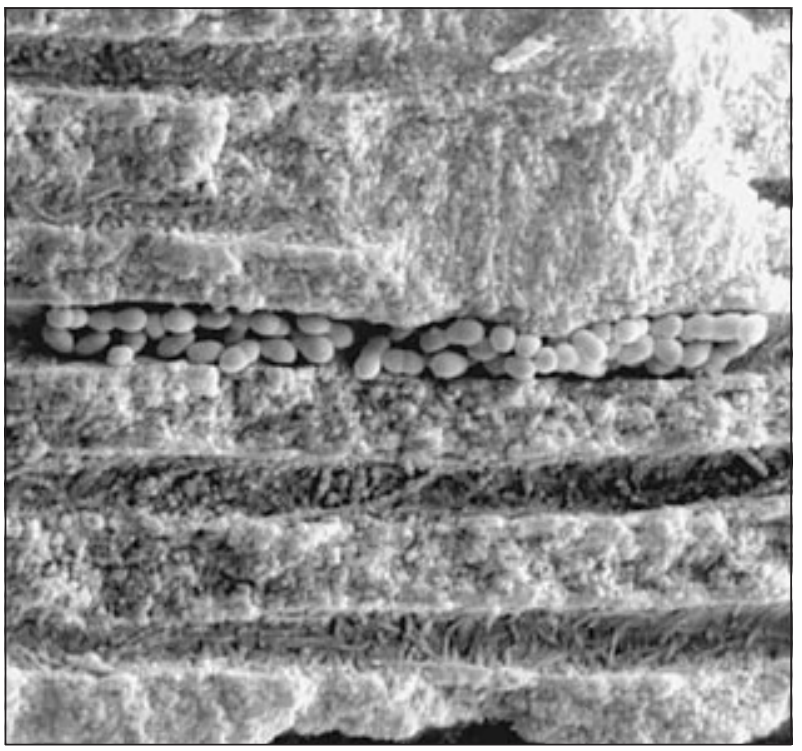

Figure 1 - Dentin infection after 60 days.

ed using Greater Taper instruments from \#12 to \#6 (Tip \#20, taper 0.12 to 0.06) (Tulsa Dentsply, Tulsa, OK, USA). ${ }^{3}$ Next, Gates-Glidden burs were used from \#6 to \#2 following the crown-down technique, followed by manual apical preparation up to a \#35 file (Maillefer Dentsply, Ballaigues, Vallorbe, Switzerland). Two test and two control groups were distributed as follows:

- G1) Single visit: $0.5 \mathrm{ml}$ of $2 \%$ chlorhexidine gel (Endogel $^{\mathrm{TM}}$, Itapetininga, SP, Brazil) and irrigation between each file (15 specimens).

- G2) Multiple visit: $0.5 \mathrm{ml}$ of $2 \%$ chlorhexidine gel (Endogel ${ }^{\mathrm{TM}}$, Itapetininga, SP, Brazil), irrigation between each file, and 14 days of calcium hydroxide intra-canal dressing (Calen ${ }^{\mathrm{TM}}$, SS White, Rio de Janeiro, RJ, Brazil) (15 specimens).

- G3) Substantivity control: $0.5 \mathrm{ml}$ of $2 \%$ chlorhexidine gel (Endogel ${ }^{\mathrm{TM}}$, Itapetininga, SP, Brazil) and 7 days of BHI culture medium intracanal dressing (5 specimens).

- G4) Positive control: $1 \mathrm{ml}$ of distilled water irrigation between each file and 7 days of $\mathrm{BHI}$ culture medium intra-canal dressing ( 5 specimens). All groups were finally irrigated with $5 \mathrm{ml}$ of distilled water.

Another sample was prepared after instrumentation. The teeth where intra-canal dressings were used (groups 2 and 3) were coronally sealed with
Cavit $^{\mathrm{TM}}$ (3M-Espe, Pilsensee, Seefeld, Germany) and incubated at $37^{\circ} \mathrm{C}$ for the established periods in an "eppendorff" with $50 \mu \mathrm{l}$ of BHI. Every 72 hours, the BHI was exchanged for a new sterile one inside the "eppendorffs". After that, another microbial sample was taken.

\section{Microbiological samples}

Bacteriologic samples were taken in the initial, post-instrumentation and post-medication phases. Sample collection started with an irrigation with $3 \mathrm{ml}$ of sterile distilled water (without the need of any mechanical removal in the post-medication phase) and was performed with \#25 sterile absorbent paper points (Tanari Ind. Ltda., Manacapuru, $\mathrm{AM}$, Brazil) that were introduced into the root canal for one minute. The infected humidified paper point collected from the root canal lumen fluid was deposited into $1.5 \mathrm{ml}$ "eppendorffs" (Elkay Products Incorporation, Shrewsbury, MA, USA) which contained $1 \mathrm{ml}$ of BHI medium. After that, each "eppendorff" was shaken for 30 seconds, followed by one hundred times dilutions.

Plates containing BHIA $+5 \%$ of defibrinated sheep blood were inoculated with $50 \mu$ l aliquots of the dilutions in triplicate. Because of the low quantity of contamination, neither the post-instrumentation G1-, G2-, or G3-group phases, nor the postmedication G2- and G3-group phases were diluted, from where $200 \mu \mathrm{l}$ aliquots were taken and used to inoculate plates as described above. After incubation for 24 hours at $37^{\circ} \mathrm{C}$, the colony forming units (CFU) were counted. The numbers counted were multiplied by 2,000 or by 5 to obtain CFU per mL. The average of the counts of the three plates of each sample was considered as the final CFU value.

In the post-instrumentation phases of the groups that used chlorhexidine (G1, G2 and G3), it was necessary to neutralize it before sampling, to prevent its adherence to the absorbent paper point. Instead of $3 \mathrm{ml}$ of distilled water irrigation, the neutralization was carried out via irrigation of the root canal using $1.5 \mathrm{ml}$ of $0.5 \%$ Tween 80 (Chemical Sigma Co., St. Louis, MO, USA) + 0.07\% Soy Lecithin (Proderma - Piracicaba, SP, Brazil). ${ }^{11}$ After that, $1.5 \mathrm{ml}$ of distilled water was used in the same manner. Then 


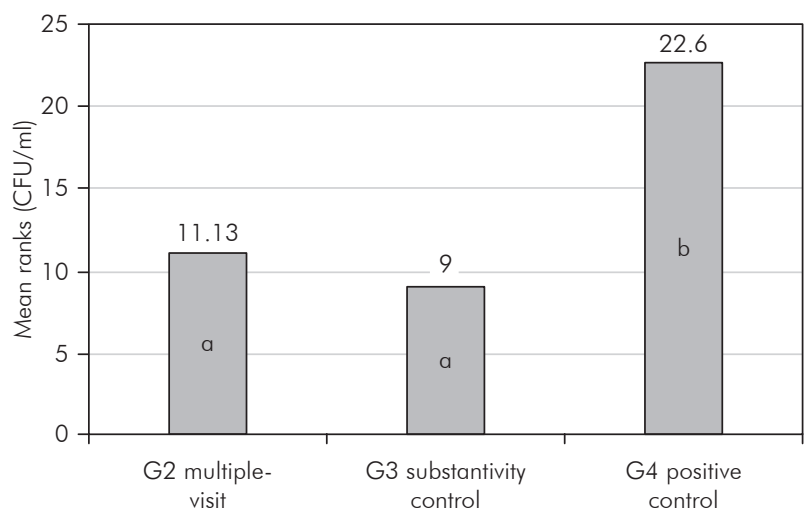

Graph 1 - Residual bacteria (E. faecalis) after the use of intra-canal dressing. Values followed by different letters presented statistically significant differences $(p<0.05)$.

the numbers of Colony Forming Units given by all the procedures (initial and post-instrumentation samples; post-instrumentation and post-medication samples; and from all final collections of each group) were evaluated as a percentage residual.

The results were statistically analyzed using a non-parametrical Kruskal-Wallis test with a level of significance of $5 \%$.

All samples were identified using colony morphology, catalysis, Gram testing and a biochemical method (Api 20 Strep, BioMérieux AS., Marcy I'Etoile, Lyon, France).

\section{Results}

The initial-period CFU counts did not present any statistical differences between any of the groups $(p>0.05)$. Disinfection with chemomechanical preparation was $100 \%$ effective in the root canal lumen due to chlorhexidine's antimicrobial ability and $96 \%$ effective when distilled water was used.

As to the dressing periods (Graph 1), the G2-calcium hydroxide group (11.1 CFU/ml) did not present any statistical differences from the G3 group $(9.0$ $\mathrm{CFU} / \mathrm{ml})(\mathrm{p}>0.05)$. However, this group allowed 3 of the 15 specimens to nurture an infection in the dressing period, whereas in group G3, none of the 5 specimens presented bacterial growth. Group G4 presented an uncontrolled bacterial growth $(22.6$ $\mathrm{CFU} / \mathrm{ml}$ ) and showed statistical differences from all other groups $(\mathrm{p}<0.05)$ and bacterial growth in 5 out of 5 specimens.

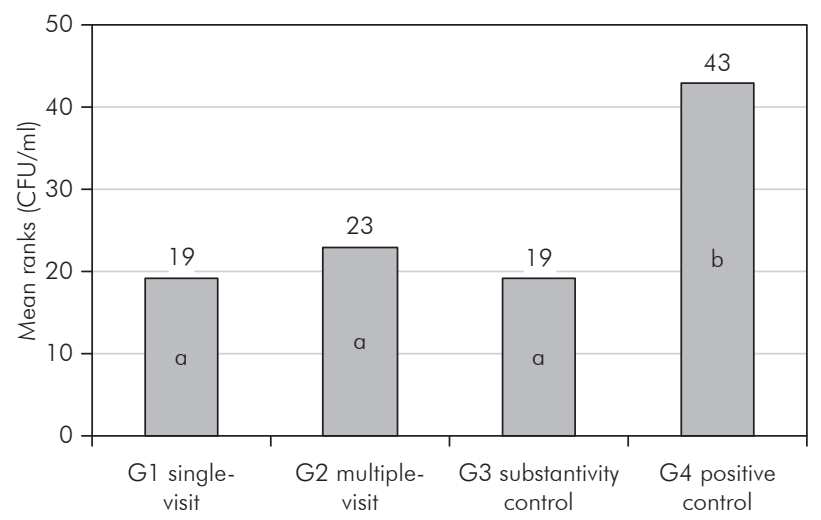

Graph 2 - Residual bacteria (E. faecalis) prior to obturation. Values followed by different letters presented statistically significant differences ( $p<0.05$ ).

The bacterial counts prior to obturation for Groups G1 (19.0 CFU/ml), G2 (23.0 CFU/ml) and G3 (19.0 CFU/ml) did not present any statistical difference between them ( $p>0.05)$. But Group G4 presented differences from all of them $(43.0 \mathrm{CFU} / \mathrm{ml})$ $(\mathrm{p}<0.05)($ Graph 2).

\section{Discussion}

E. faecalis is a bacteria that has great resistance, maintaining itself viable in high $\mathrm{pH}$ levels, possessing the capacity to invade dentinal tubules and adhere to collagen in the presence of human serum, keeping its survival methods intact. This can be related to its virulence factor in endodontically failed teeth, maintaining periapical diseases. ${ }^{12}$ In the present study, Crown-down preparation with $2 \%$ chlorhexidine reduced infection up to $100 \%$ in the root canal lumen, where the greater part of infection is. The shallow dentinal tubules were removed by instrumentation cutting. Deep inside dentinal tubules, however, residual bacteria cannot be eradicated and can grow and repopulate the entire system. ${ }^{20}$ Therefore, it is necessary to fill the root canal as quickly as possible or a strong antimicrobial intra-canal dressing must be used.

Haapasalo et al. ${ }^{8}$ (2000) stated that the poor diffusion of hydroxyl ions into infected dentin and the buffering capacity of dentin can reduce its alcalinization potential, and calcium hydroxide pastes became ineffective against E. faecalis even after an extended time of incubation. On the other hand, Siqueira 
Jr., Uzeda ${ }^{18}$ (1997) showed that the combination between calcium hydroxide and camphorated paramonochlorophenol was effective to disinfect bovine dentinal tubules against $E$. faecalis after one day of exposure. In contrast, the teeth were not cleaned nor shaped, so the intra-canal dressing was the only resource used to disinfect all contaminated dentin, and it is known that cleaning, shaping and irrigating the root canal greatly reduces the number of bacteria. ${ }^{14}$

There is no evidence, however, that any special measures should be taken to kill bacteria inside dentinal tubules. Root canal filling immediately after cleaning and shaping allows the remaining bacteria to be either inactivated or prevented from repopulating the canal space. Those bacteria do not appear to jeopardize the successful outcome of root canal treatment. ${ }^{14,16}$

When the root canal filling is performed immediately after chemomechanical preparation, it removes all space and nutrients necessary to maintain bacterial viability, and the residual bacteria inside dentinal tubules will perish without nutrients. The common recovery of E. faecalis in root canals of teeth presenting endodontic-treatment failure implies that this species is intimately involved in the pathogenesis and maintenance of persisting apical periodontitis. A proton pump mechanism with the capacity to acidify the cytoplasm by pumping protons to its interior is critical for its survival at high $\mathrm{pH}$ levels. ${ }^{4}$

In this study, we removed the root cementum to expose dentinal tubules with a $17 \%$ EDTA bath, thus optimizing the infection also on the external root walls. Cementum is a valid barrier against the penetration of bacteria. ${ }^{20}$

As shown by scanning electron microscopy, infection was found to be deeply located in the dentinal tubules with the 60-days contamination protocols. Cementum removal permits constant culture medium supply in infected dentin, contributing also to optimize microbial growth rates inside dentinal tubules. Cementum removal is important for the residual bacteria inside dentinal tubules that will survive with nutrients and space for their growth. ${ }^{9}$

As shown in the present results, antimicrobial irrigant properties are very important to optimize intra-canal disinfection. The $2 \%$ chlorhexidine-gel irrigation did not permit residual bacterial growth, even when it was encouraged with a seven-day intracanal dressing with BHI culture medium, because of its substantive antimicrobial action. On the other hand, irrigation with distilled water plus a seven-day intra-canal dressing with BHI culture medium promoted more bacterial growth than the groups using irrigation which had antimicrobial properties.

Ferraz et al. ${ }^{5}$ (2001) already had shown that $2 \%$ chlorhexidine gel used as an endodontic irrigant has antimicrobial activity against almost all microorganisms commonly found in endodontic microflora; and Gomes et al. ${ }^{7}$ (2001) presented the disinfection times of chlorhexidine in different concentrations and vehicles necessary to effectively eradicate $E$. faecalis. The $2.0 \%$ concentrations of liquid and gel chlorhexidine and $5.25 \%$ sodium hypochlorite presented the shortest times.

Almyroudi et al. ${ }^{1}$ (2002) showed that, over a period of 3 to 14 days, only the calcium hydroxide (14 days) used as intra-canal dressing resulted in positive cultures, whereas chlorhexidine in gel form, either associated or not to calcium hydroxide, did not permit $E$. faecalis growth.

The bacterial counts prior to root canal filling indicated that both single- and multiple-visit root-canal treatment groups disinfected the root canal lumen to the same degree; however, the multiple-visit (G2) group left 3 out of 15 specimens with a positive bacterial count prior to filling. The single-visit (G1 and G3) groups both showed only negative bacterial samples. So some E. faecalis deep within the dentinal tubules survived and grew in the presence of calcium hydroxide.

Since 1970, Rolla et al. ${ }^{17}$ had shown that chlorhexidine adsorbs onto hydroxiapatite, being released when its concentration in the environment decreases, inhibiting bacterial growth. Lenet et al. ${ }^{11}$ (2000) showed that $2 \%$ chlorhexidine-gel-treated bovine dentin acquires antimicrobial immunity for a period of at least 21 days against $E$. faecalis, thus contributing to more important properties that recommend its clinical use. Probably in group G3, chlorhexidine's residual effect continued to inhibit reinfection even after 7 days of BHI intra-canal dressing. Solutions used in endodontics should preferentially have low toxic effects. Tanomaru-Filho et al. ${ }^{19}$ (2002) studied the inflammatory response 
to $2 \%$ chlorhexidine digluconate, and described it as being a non significant inflammatory response in vivo, whereas $0.5 \%$ sodium hypochlorite significantly increased the inflammatory-cell migrations, thus proving chlorhexidine's biocompatibility in high concentrations.

\section{Conclusion}

Within the limits of this study, the following conclusions can be made:

1. No statistical differences were found between the results of single-visit and multiple-visit rootcanal treatment disinfections.

\section{References}

1. Almyroudi A, Mackenzie D, Mchugh S, Saunders WP. The effectiveness of various disinfectants used as endodontic intracanal medications: an in vitro study. J Endod. 2002;28(3):163-7.

2. Ashkenaz PJ. One-visit endodontics. Dent Clin North Am. 1984;28(4):853-63.

3. Buchanan LS. The shape of things to come. Dent Today. 1994;13(5):40-7.

4. Evans M, Davies JK, Sundqvist G, Figdor D. Mechanisms involved in the resistance of Enterococcus faecalis to calcium hydroxide. Int Endod J. 2002;35(3):221-8.

5. Ferraz CCR, Gomes BPFA, Zaia AA, Teixeira FB, SouzaFilho FJ. In vitro assessment of the antimicrobial action and the mechanical ability of chlorhexidine gel as an endodontic irrigant. J Endod. 2001;27(7):452-5.

6. Gomes BPFA, Ferraz CCR, Garrido FD, Rosalen PL, Teixeira FB, Souza-Filho FJ. Microbial Susceptibility to calcium hydroxide pastes and their vehicles. J Endod. 2002;28(11):758-61.

7. Gomes BPFA, Ferraz CCR, Vianna ME, Berber VB, Teixeira $\mathrm{FB}$, Souza-Filho FJ. In vitro antimicrobial activity of several concentrations of sodium hypochlorite and chlorhexidine gluconate in the elimination of Enterococcus faecalis. Int Endod J. 2001;34(6):424-8.

8. Haapasalo HK, Sirén EK, Waltimo TM, Ørstavik D, Haapasalo MP. Inactivation of local root canal medicaments by dentin: an in vitro study. Int Endod J. 2000;33(2):126-31.

9. Haapasalo M, Ørstavik D. In vitro infection and disinfection of dentinal tubules. J Dent Res. 1987;66(8):1375-9.

10. Heling I, Steinberg D, Kenig S, Gavrilovich I, Sela MN, Friedman M. Efficacy of a sustained release device containing chlorhexidine and $\mathrm{Ca}(\mathrm{OH})_{2}$ in preventing secondary infection of dentinal tubules. Int Endod J. 1992;25(1):20-4.

11. Lenet BJ, Komorowski R, Wu XY, Huang J, Grad H, Lawrence HP et al. Antimicrobial substantivity of bovine root dentin exposed to different chlorhexidine delivery vehicles. J Endod. 2000;26(11):652-5.
2. Chemomechanical preparation with $2 \%$ chlorhexidine disinfects up to $100 \%$ of E. faecalis inside the root canal lumen.

3. Chlorhexidine's substantivity properties improve its disinfection capability even in the other treatment phases (initial instrumentation, post instrumentation, post medication).

\section{Acknowledgements}

The authors wish to thank the NAP MEPA-ESALQ-USP (Center for the Support of SEM Research Applied to Agriculture Luiz de Queiroz Higher School of Agriculture), Piracicaba-Brazil.

12. Love RM. Enterococcus faecalis - a mechanism for its role in endodontic failure. Int Endod J. 2001;34(5):399-405.

13. Perez F, Calas P, Falguerolles A, Maurette A. Migration of a Streptococcus sanguis strain through the root dentinal tubules. J Endod. 1993;19(6):297-301.

14. Peters LB, Van Winkelhoff AJ, Buijs JF, Wesselink PR. Effects of instrumentation, irrigation and dressing with calcium hydroxide on infection in pulpless teeth with periapical bone lesions. Int Endod J. 2002;35(1):13-21.

15. Peters LB, Wesselink PR. Periapical healing of endodontically treated teeth in one and two visits obturated in the presence or absence of detectable microorganisms. Int Endod J. 2002;35(8):660-7.

16. Peters LB, Wesselink PR, Moorer WR. The fate and the role of bacteria left in root dentinal tubules. Int Endod J. 1995;28(2):95-9.

17. Rölla G, Löe H, Schiott CR. The affinity of chlorhexidine for hydroxyapatite and salivary mucins. J Periodontal Res. 1970;5(2):90-5.

18. Siqueira Jr JF, Uzeda M. Intra-canal medicaments: evaluation of the antibacterial effects of chlorhexidine, metronidazole, and calcium hydroxide associated with three vehicles. J Endod. 1997;23(3):167-9.

19. Tanomaru Filho M, Leonardo MR, Silva LAB, Aníbal FF, Faccioli LH. Inflammatory response to different endodontic irrigating solutions. Int Endod J. 2002;35(9):735-9.

20. Vivacqua-Gomes N, Gurgel-Filho ED, Gomes BP, Ferraz CC, Zaia AA, Souza-Filho FJ. Recovery of Enterococcus faecalis after single- or multiple-visit root canal treatments carried out in infected teeth ex vivo. Int Endod J. 2005;38(10):697-704.

21. Weiger R, Rosendahl R, Löst C. Influence of calcium hydroxide intra-canal dressings on the prognosis of teeth with endodontically induced periapical lesions. Int Endod J. 2000;33(3):219-26. 